\title{
レーザー高次高調波による分子ダイナミクスの超高速光電子分光
}

\author{
伏谷 瑞穂 $^{1}$ ，菱川 明栄 ${ }^{1,2}$ \\ 1名古屋大学大学院 理学研究科 物質理学専攻(化学系) ( ₹464-8602 愛知県名古屋市千種区不老町) \\ 2名古屋大学物質科学国際研究センター（广464-8602 愛知県名古屋市千種区不老町）
}

\section{Ultarafast Photoelectron Spectroscopy of Molecular Wavepacket Dynamics by Laser High-Order Harmonics}

\author{
Mizuho FUSHITANI ${ }^{1}$ and Akiyoshi HISHIKAWA ${ }^{1,2}$ \\ ${ }^{1}$ Department of Chemistry, Graduate School of Science, Nagoya University, Furo-cho, Chikusa-ku, Nagoya, Aichi 464-8602 \\ ${ }^{2}$ Research Center for Materials Science, Nagoya University, Furo-cho, Chikusa-ku, Nagoya, Aichi 464-8602
}

(Received September 28, 2015)

\begin{abstract}
Laser high-order harmonics in the extreme ultraviolet (EUV) and soft X-ray region serve as a unique tool to study ultrafast molecular dynamics associated with valence or inner-shell electron excitations. The harmonics are often obtained as a train of pulses, which result in a spectrum with a comb consisting of the odd harmonic orders. However, it is often the case that isolated pulses rather than pulse trains are preferred in the conventional pump-probe spectroscopy, to avoid signal overlaps associated with different harmonic orders. Here we review our approach for the single-order harmonics generation in EUV by using dielectric multilayer mirrors and metal foils, and the application to photoelectron spectroscopy on wavepacket dynamics of simple molecules such as $\mathrm{Br}_{2}, \mathrm{I}_{2}$ and $\mathrm{N}_{2}$.
\end{abstract}

Key Words: Single-order high harmonics, Photoelectron spectroscopy, Wavepacket dynamics

\section{1. はじめに}

シンクロトロン放射やレーザー誘起プラズマを利用し た光源技術の発展は極紫外 $(\mathrm{EUV}) \cdot \mathrm{X}$ 線域における時間 分解分光の分解能を飛躍的に向上させ, これらを利用し たサブピコ秒領域の超高速ダイナミクスに関する研究が 気体や溶液, 固体表面などにおいて進められるように なった ${ }^{1-3)}$ 。これに対して1990年代に入り, 高強度超短 パルスレーザーを希ガスなどの非線形媒質に集光するこ とで, 極紫外から軟X線に達する高次高調波を発生でき ることが明らかとなっだ)。この高次高調波はコヒーレ ンスの良い光源であり, そのパルス幅はアト秒の時間ス ケールに達するため, 既存の光源では観測が困難であっ た, 内殼正孔緩和 ${ }^{5)}$ や分子内電荷移動 ${ }^{6)}$ な゙の超高速過 程の実時間計測が行われている。 また, 高次高調波は水 溶液中の生体分子を実時間イメージングするコヒーレン 卜光源としても注目を集めており，近年，特に「水の空」 と呼ばれる2-4 nmの波長域における高次高調波発生お よびその高出力化が推し進められている7,8).

一方これらと平行して, 真空紫外・極紫外域(波長： 10-200 nm)の高調波を利用した実時間計測の開拓が進 められている. 特に摂動領域の非線形過程で発生する高 調波を利用することによって，計測に十分な光子フラッ
クスを容易に得ることができる ${ }^{9,10)}$ 。また，多くの分子 が価電子吸収による大きな吸収断面積をもつことから, この波長域の高次高調波はリュードベリ状態など高励起 状態の生成や，価電子励起に伴うコヒーレントな核波束 運動, あるいは分子反応過程などの光電子計測における プローブ光として際立った特徴をもつ光源として利用さ れている。一方, 高次高調波は一般に複数の次数を伴っ て発生するため, 計測に必要な次数の高調波を選択的に 取り出すための工夫が必要である ${ }^{9-14)}$ ，本稿では，筆者 らが進めてきた極紫外域における単一次数高調波光源の 開発とその超高速光電子分光への応用について紹介す る.

\section{2. 単一次数高調波の発生}

レーザー高調波の発生は3次や5次などの比較的低い次 数の場合には摂動展開した非線形分極によって理解され る。一方，高次高調波発生は非摂動論的な「3ステップモ デル」 $\rfloor^{15)}$ で理解される. 後者では(1)トンネルイオン化に よる電子放出，（2）レーザー電場による電子加速，（3）イ オンコアとの再結合による光放出, によって極紫外から 軟X線領域に至る超短パルス光が得られる。この光放出 過程は基本波の搬送周期の半周期毎に起こるため, 高次 


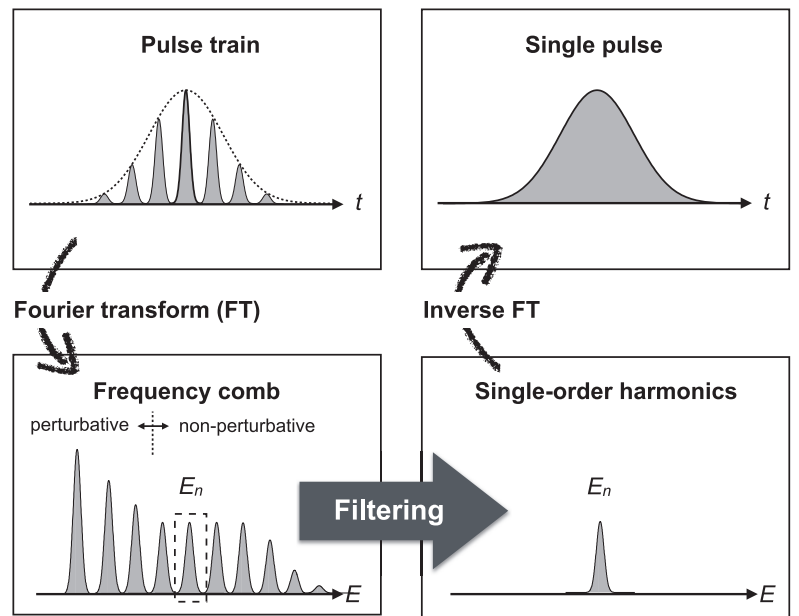

Fig. 1 Schematics of single pulse generation by using spectral filtering of laser high order harmonics.

高調波は単一パルスではなくパルス列として発生する。 周波数領域では高次高調波は奇数次の高調波からなる周 波数コムとして観測される(Fig. 1). このため, 例えば 高次高調波を光電子分光に用いた場合には, イオン化し きい值を越える光子エネルギーをもつ様々な次数の高調 波によって光電子が生じ, スペクトルにはこれらの寄与 が互いに重畳した形で観測される。このため特に実時間 計測への応用においては, 異なった電子状態におけるダ イナミクスがポンプ・プローブ信号に反映されることに なる。このような問題を避けるためには, 高調波のうち 必要な次数たけを計測に使用することが望ましい。高調 波の特定の次数のみを発生することは困難なため, 回折 格子 ${ }^{11-13)}$ や誘電体多層膜ミラー ${ }^{14)}$ など光学素子を用い た周波数選別によって次数選択が行われる. 単一次数高 調波のフーリエ限界における時間幅は次数選択された際 のスペクトルの帯域幅に依存する.

\section{3. 実験装置}

Fig. 2に筆者らが使用している実験装置の概略図を示 す。再生増幅チタンサファイアレーザーシステムからの 出力 ( $800 \mathrm{~nm},<40 \mathrm{fs}, 1 \mathrm{kHz})$ の一部を平凸レンズに より高真空チャンバー内に設置した高調波セル（希ガス， 10-100 Torr) に集光する. 発生した高次高調波は光学素 子により単一次数の高調波パルスに変換された後, 凹面 鏡を用いて相互作用領域中の気体試料に集光される。 の高調波パルスに対して遅延時間をおいたフェムト秒 レーザーパルスを導入する. ポンプ光およびプローブ光 照射によって相互作用領域に生成した光電子を磁気ボト ル型光電子分光器を用いて検出する.

単一次数高調波の次数選択には必要とする波長域に応 じて, 金属薄膜 (透過)や誘電体多層膜ミラー(反射)など を使用する。基本波 $800 \mathrm{~nm}$ の 27 次高調波 $(h v=42 \mathrm{eV})$ を 単一パルスとして発生させる場合は, $\mathrm{SiC} / \mathrm{Mg}$ をコート した誘電体多層膜ミラーを使用する. Fig. 3 (a)に示し たようにこのミラーの反射率は27次のエネルギー位置 で最大, それ以外の次数の位置では一桁以上小さくなる

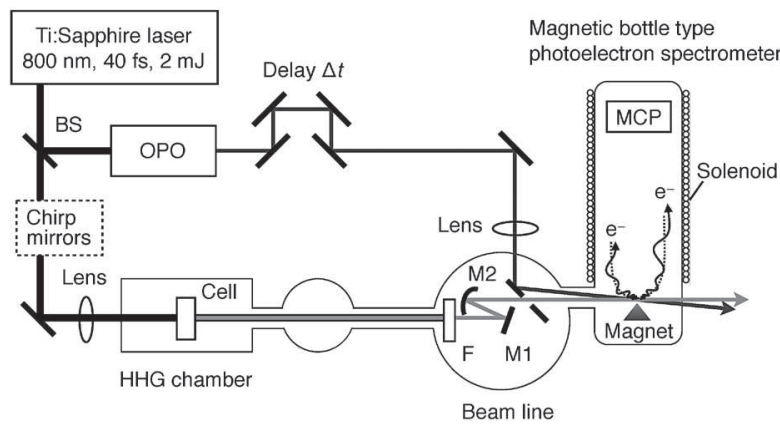

Fig. 2 Schematic diagram of experimental set up for time-resolved photoelectron spectroscopy using single-order harmonics in EUV. F: Metal filter, M1, M2: Dielectric multilayer mirrors.
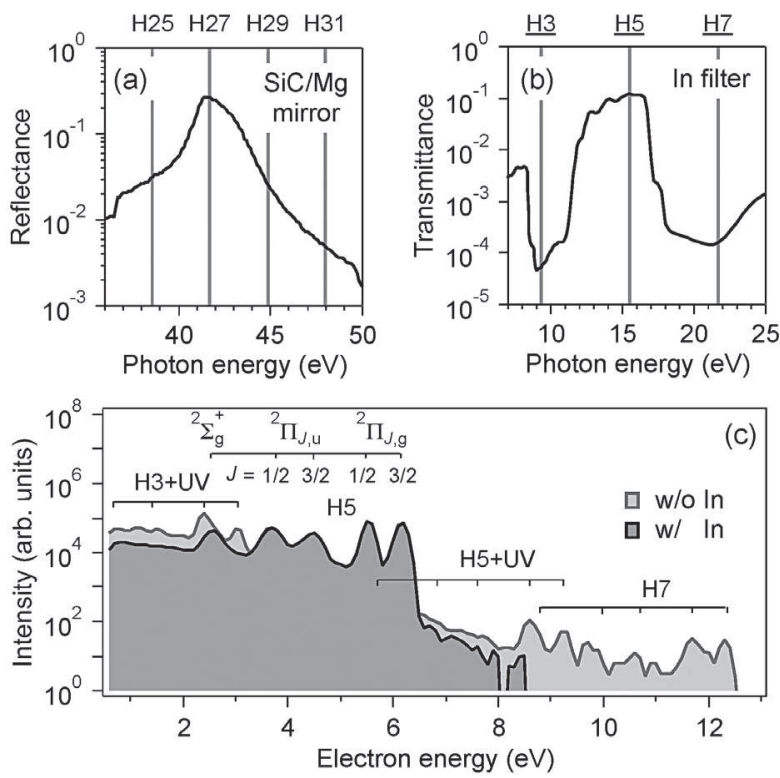

Fig. 3 (a) Reflectance of $\mathrm{SiC} / \mathrm{Mg}$ multilayer mirror in the region of $h v=35-50 \mathrm{eV}$. The reflectance is optimized for the 27 th order harmonics of the driving laser pulse at $800 \mathrm{~nm}$. (b) Transmittance of Indium (In) filter $(0.1 \mu \mathrm{m})$ in the region of $h v=7-25 \mathrm{eV}$. Energy positions of high harmonics of the fundamental UV pulse at $400 \mathrm{~nm}$ are indicated as sticks. (c) Photoelectron spectra of $\mathrm{I}_{2}$ molecules by using laser high order harmonics with and without the In filter.

ように設計されている。基本波や低い次数の高調波を除 去するため，アルミ薄膜フィルターを併用する.

金属薄膜フィルターを用いた手法は簡便であるが，透 過可能な波長域や帯域幅は物質固有の性質に依存してい る。例えば，インジウム薄膜はFig. 3 (b) に示すように 光子エネルギーが13-16 eVの極紫外光に対して高い透過 率を持つような幅広い帯域幅を示す. $800 \mathrm{~nm}$ の基本波 を用いて高次高調波を発生させた場合には，この帯域幅 内に複数の次数の高調波が含まれる。このような場合, 単一次数の高調波を得るためには, 周波数コムのエネル ギー間隔を広げ，透過帯域に含まれる高次高調波を限定 する必要がある。筆者らは基本波の波長を $400 \mathrm{~nm}$ とす ることで，5次高調波 $(15.5 \mathrm{eV})$ のみを選択的に透過さ 
せ, 単一次数高調波の発生を行っている. 近赤外域に比 べて紫外域ではレンズ, 光学密や空気などによる分散が 顕著になるため，基本波のパルス幅が最短となるよう に，チャープミラーを用いて分散補償する。

Fig. 3 (c) に5次の単一次数パルスを用いたヨウ素分子 の光電子スペクトル計測の結果を示す. 次数選択を行わ ない場合には，5次高調波の成分に加えて，3次および7 次高調波，さらにこれらと基本波の和周波に起因する成 分が光電子スペクトル上に現れている。一方，インジウ 厶薄膜 $(\sim 0.1 \mu \mathrm{m})$ を挿入した場合には，5次高調波に由 来する光電子ピークのみが観測され，インジウム薄膜 フィルターを利用することにより単一次数高調波が得ら れることがわかる。

\section{4. 超高速光電子分光への応用}

終状態からの発光を信号とするポンプ・プローブ計測 では, ポンプ光により振動波束が生成した電子状態と, プローブ光により遷移する束縛終状態との間で大きな遷 移確率をもつフランクコンドン空を利用して核波束の追 跡を行う。この場合, プローブ光の波長は観測する分子 座標領域にあわせて設定する必要がある。これに対し て, イオン化による光電子を観測した場合, 核間距離に 依存して励起状態および終状態間のポテンシャルエネル ギー差が変化し，この違いが光電子運動エネルギーに反 映されるため, 単一の波長で核波束運動を分子座標の広 い範囲にわたって追跡できる，光電子分光を用いて実時 間追跡を行うには，束縛状態間遷移に用いられる可視 · 紫外光よりも高い光子エネルギーをもつ真空紫外・極紫 外域における超短パルスが必要であるが, 高次高調波は これに適した光源の一つである。

\section{$4.1 \mathrm{Br}_{2}$ 分子の超高速解離ダイナミクス}

$\mathrm{SiC} / \mathrm{Mg}$ 多層膜ミラーにより次数選択した 27 次高調波 $(h v=42 \mathrm{eV})$ をプローブ光源として応用した例として, 臭素 $\left(\mathrm{Br}_{2}\right)$ 分子のC $\mathrm{C}^{1} \Pi_{1 \mathrm{u}}$ 状態における超高速解離過程につ いて紹介する. Fig.4 (a)に示したように, この解離過 程ではポンプ光(波長 $400 \mathrm{~nm}, h v=3.1 \mathrm{eV}, \sim 80 \mathrm{fs}$ ) に よって $\mathrm{C}^{1} \Pi_{1 \mathrm{u}}$ 状態に励起された $\mathrm{Br}_{2}$ 分子から基底状態の $\mathrm{Br}$ $\left({ }^{2} \mathrm{P}_{3 / 2}\right)$ 原子が生成する. Fig. 4 (b) にBr原子の信号強度の ポンプ・プローブ遅延時間依存性を示す ${ }^{14)}$. $\mathrm{Br}$ 原子の信 号強度は $\Delta t>0 \mathrm{fs}$ で現れ, 約 $80 \mathrm{fs}$ の立ち上がりの後, 一 定の值を示した。

この信号強度の時間変化を調べるため, $\mathrm{C}^{1} \Pi_{1 \mathrm{u}}$ 状態に おける $\mathrm{Br}_{2}$ 分子の振動波束計算を行った。 中性 $\mathrm{Br}_{2}$ のC $\mathrm{C}_{1 \mathrm{u}}$ 状態と $\mathrm{Br}_{2}{ }^{+}$イオンの $\mathrm{X}^{2} \Pi_{3 / 2 \mathrm{~g}}$ 状態のポテンシャルエネル ギー差を考慮したところ, $\mathrm{Br}_{2}$ 分子の光電子エネルギー は核間距離 $R$ が $6.2 \mathrm{au}$ 以上において, $\mathrm{Br}$ 原子に対応する 光電子エネルギー $(\sim 30 \mathrm{eV})$ とほぼ一致することがわ かった。 そこで, $\mathrm{C}^{1} \Pi_{1 \mathrm{u}}$ 状態における $\mathrm{Br}_{2}$ 分子の振動波束 のうち $R=6.2 \mathrm{au}$ 以上に広がった成分を $\mathrm{Br}$ 原子の光電子 信号としてその時間依存性を計算したところ, 実験結果 をよく再現することがわかった(Fig.4(b) 実線)，観測結

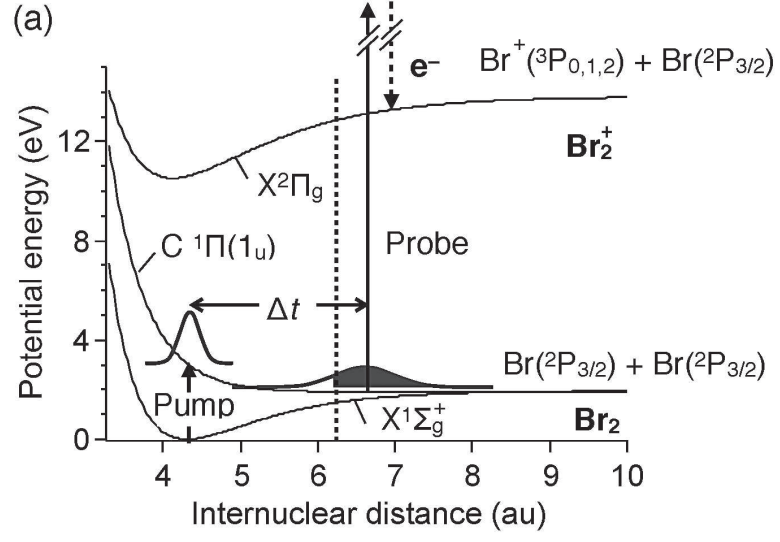

(b)

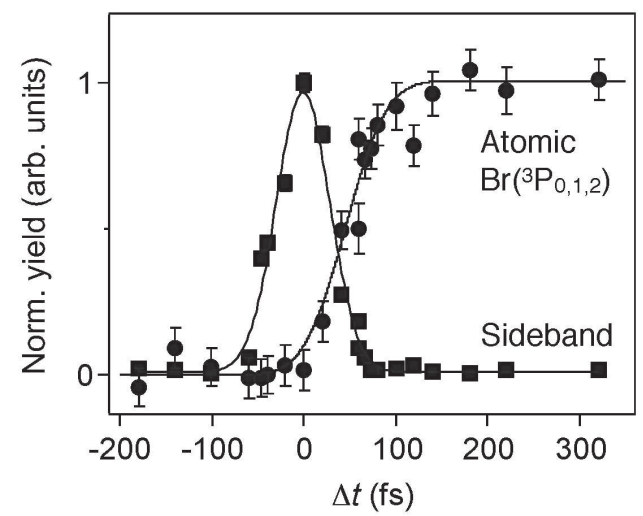

Fig. 4 (a) Relevant potential curves for $\mathrm{Br}_{2}$ and $\mathrm{Br}_{2}^{+}$. (b) Temporal behavior of integrated intensities of the $\operatorname{Br}\left({ }^{3} \mathrm{P}_{0,1,2}\right)$ peak $(\bigcirc)$. The zero time-delay $(\Delta t=0)$ is determined by using the sideband intensity profile ( $\square$ ) of the $X^{2} \Pi_{\mathrm{g}}$ peak.

果は同じC $\mathrm{C}_{1 \mathrm{u}}$ 状態において以前に観測された信号 $\left(500 \mathrm{fs}^{12)}, 150 \mathrm{fs}^{13)}\right)$ に比べて速やかな立ち上がり時間を 示しており，我々の計測系が回折格子を用いた従来の計 測系に比へ，高い時間分解能を有することを示してい る。これは主として, 誘電体多層膜ミラーを用いること によって超短パルス高調波( 30 fs) が得られることを反 映している.

\section{$4.2 \mathrm{I}_{2}$ 分子の振動波束ダイナミクス}

Fig. 5 (a)にヨウ素 $\left(\mathrm{I}_{2}\right)$ 分子と $\mathrm{I}_{2}{ }^{+}$イオンのポテンシャル およびポンプ・プローブ計測の概略図を示す. $\mathrm{B}^{3} \Pi^{+}{ }_{0 \mathrm{u}}$ 状 態の解離極限を越える可視域ポンプ光(波長 $490 \mathrm{~nm}$, $h v=2.53 \mathrm{eV}, \sim 50 \mathrm{fs})$ により $\mathrm{I}_{2}$ 分子を励起すると，振動 波束が $\mathrm{B}^{3} \Pi_{0 \mathrm{u}}^{+}$状態および $\mathrm{B}^{\prime \prime} \Pi_{1 \mathrm{u}}$ 状態に生成する。生成し た振動波束は異なるポテンシャル上を運動し, $\mathrm{B}^{3} \Pi^{+}{ }_{0 \mathrm{u}}$ 状 態では $\mathrm{I}_{2} \rightarrow \mathrm{I}\left({ }^{2} \mathrm{P}_{3 / 2}\right)+\mathrm{I}^{*}\left({ }^{2} \mathrm{P}_{1 / 2}\right), \quad \mathrm{B}^{\prime \prime 1} \Pi_{1 \mathrm{u}}$ 状態では $\mathrm{I}_{2} \rightarrow \mathrm{I}\left({ }^{2} \mathrm{P}_{3 / 2}\right)$ $+\mathrm{I}\left({ }^{2} \mathrm{P}_{3 / 2}\right)$ へと解離する。この解離したヨウ素原子を極紫 外超短パルス (波長 $80 \mathrm{~nm}, h v=15.5 \mathrm{eV}$ )によりプローブ することで，単一波長で励起された異なる電子状態にお ける振動波束ダイナミクスを同時に追跡できる.

ポンプ・プローブ遅延時間が $\Delta t=640 \mathrm{fs}$ のきの $\mathrm{I}_{2}$ 分 子の光電子スペクトルをFig. 5 (b) に示す. プローブ光 の光子エネルギー $(h v=15.5 \mathrm{eV})$ は $\mathrm{I}_{2}$ 分子のイオン化しき い值 $(9.3 \mathrm{eV})$ を越えるため, ポンプ光の有無に関わら 

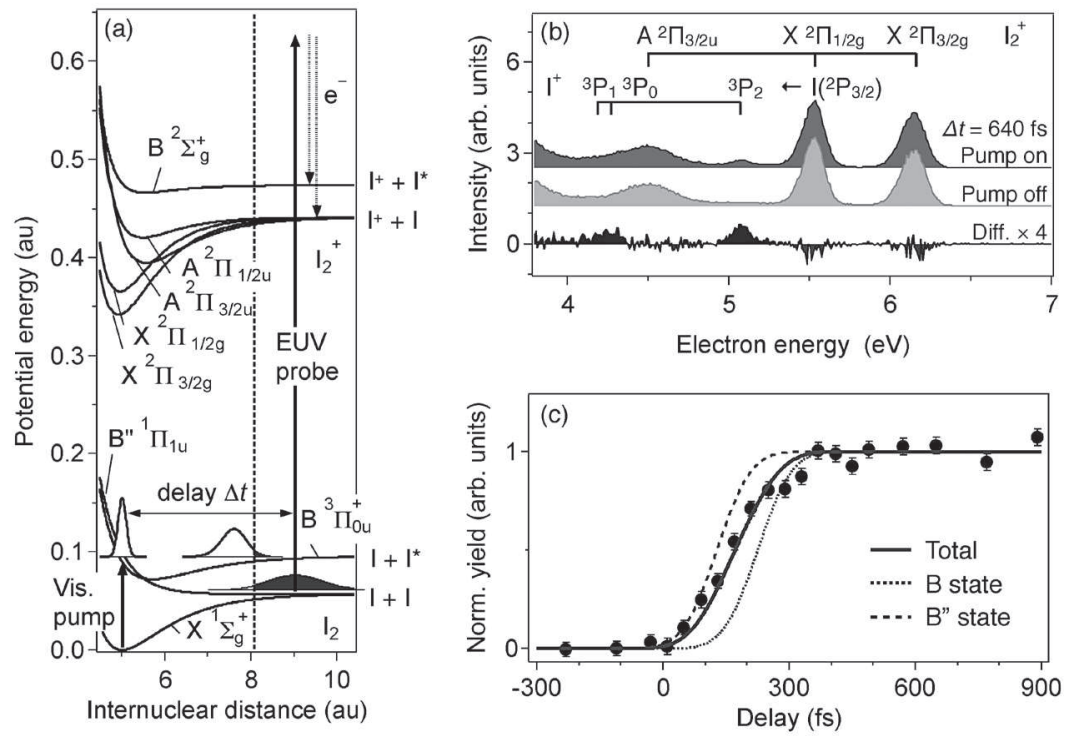

Fig. 5 (a) Part of potential curves of $\mathrm{I}_{2}$ and $\mathrm{I}_{2}^{+}$molecules. Sequence of the visible pump and EUV probe pulses is also shown. (b) Photoelectron spectrum of $\mathrm{I}_{2}$ by the pump $(h v=2.53 \mathrm{eV})$ and probe $(h v=15.5 \mathrm{eV})$ pulses at $\Delta t=640$ fs (top) and spectrum by the probe pulse only (middle). The net photoelectron spectrum (bottom) is obtained by subtracting the middle trace from the top one. (c) Integrated intensities of the ${ }^{3} \mathrm{P}_{2}$ peak of I atoms as a function of the pump-probe time delay. Simulated curves of the ${ }^{3} \mathrm{P}_{2}$ peak of I atoms: $\mathrm{B}^{3} \Pi^{+}{ }_{0 \mathrm{u}}$ (dotted), $\mathrm{B}{ }^{, 1} \Pi_{1 \mathrm{u}}$ (broken), and both (solid) states.

ず， $\mathrm{I}_{2}$ 分子の光電子ピークが観測される。一方，プロー ブ光とともにポンプ光を照射したスペクトルには 4.3 扔 よび5.1 eVに新たなピークが現れている。 エネルギー保 存則から，これらのピークは解離生成物である $\mathrm{I}\left({ }^{2} \mathrm{P}_{32}\right)$ 原 子からの光電子信号に帰属される ${ }^{10)}$

光電子エネルギー $5.1 \mathrm{eV}$ に㧍ける $\left({ }^{2} \mathrm{P}_{3 / 2}\right)$ 原子の信号強 度をポンプ・プローブ遅延時間の関数としてプロットし た図をFig. 5 (c) に示す. $\left.\mathrm{I}^{2}{ }^{2} \mathrm{P}_{3 / 2}\right)$ 原子の光電子信号は $\mathrm{I}_{2}$ 分 子の解離過程を反映して, 遅延時間とともに単調増加 し, 約300 fsで最大值を示し, その後は一定の值となる 振舞いを示した。この時間依存性を調べるため, $\mathrm{B}^{3} \Pi^{+}{ }_{0 \mathrm{u}}$ 状態またはB"1 $\Pi_{1 \mathrm{u}}$ 状態に扔ける振動波束計算を行った。 ただし，この波束計算では $\mathrm{I}_{2}$ 分子の核間距離が $8.1 \mathrm{au}$ 上にある波束部分が $5.1 \mathrm{eV}$ の光電子ピーク (幅 $0.24 \mathrm{eV}$ )に 対応しているため, これを $\mathrm{I}\left({ }^{2} \mathrm{P}_{3 / 2}\right)$ 原子の信号とした。 $\mathrm{B}^{3} \Pi^{+}{ }_{0 \mathrm{u}}$ 状態または $\mathrm{B}^{\prime 1} \Pi_{\mathrm{lu}}$ 状態のみを考慮した場合, 波束 計算の結果 (Fig. 5 (c) 点線挹よび破線) は実験結果を再

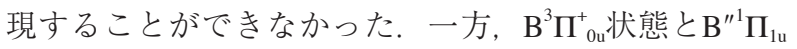
状態の $h v=2.53 \mathrm{eV}$ に扔ける吸収断面積㧍よび各解離過 程に扮ける $\mathrm{I}\left({ }^{2} \mathrm{P}_{3 / 2}\right)$ 原子の生成比を考量し, $\mathrm{B}$ 㧍よびB“状 態に打ける理論曲線を 0.63 対 0.37 の割合で足し合わせて 得られた計算結果(実線) は実験結果と良い一致を示し た ${ }^{10)}$ 。これは異なる電子状態に扔ける解離過程を同時に 実時間追跡できることを意味している。

一方, ポンプ光の光子エネルギーを $h v=2.25 \mathrm{eV}$ (波長 $550 \mathrm{~nm})$ とした場合には, $\mathrm{B}^{3} \Pi_{0 \mathrm{u}}^{+}$状態の振動準位 $\mathrm{v}=23$ を 中心として振動波束が生成され，この振動波束は束縛ポ テンシャル上で周期的な運動を行う。この振動波束運動 を実時間で追跡するため, 単一次数高調波パルス $(h v=15.5 \mathrm{eV})$ をプローブ光として光電子分光を行っ た. Fig. 6 (a)にプローブ光のみによる信号を除去した $I_{2}$ 分子の光電子スペクトルの時間変化を示す。遅延時間
$\Delta t=0 \mathrm{fs}$ において7.7および $8.4 \mathrm{eV}$ に観測された光電子

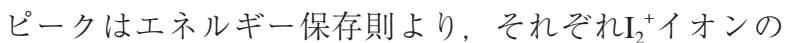
$\mathrm{X}^{2} \Pi_{1 / 2 \mathrm{~g}}$ 打よび $\mathrm{X}^{2} \Pi_{3 / 2 \mathrm{~g}}$ 状態を終状態として放出された光電 子信号(およびそのサイドバンド)に対応している。これ らの光電子ピークは $\Delta t=100 \mathrm{fs} に は$ 消失するものの, $7.7 \mathrm{eV}$ の光電子ピークは $\Delta t \sim 400 \mathrm{fs} に$ 再び現れ，その後 も約400 fsの周期で信号強度が繰り返し回復しているこ とがわかる。この周期はv $=23$ の古典振動周期 $(380 \mathrm{fs}$ ) と良い一致を示していることから，この成分は $\mathrm{B}^{3} \Pi^{+}{ }_{04}$ 状 態に扔ける振動波束運動に帰属することができる。

観測された振動波束ダイナミクスを詳しく調べるた め, 終状態を $\mathrm{I}_{2}{ }^{+}$イオンの $\mathrm{X}^{2} \Pi_{1 / 2 \mathrm{~g}}$ 状態とした波束計算を 行ったところ, Fig. 6 (b)に示す光電子スペクトルの時 間変化が得られた. $7.7 \mathrm{eV}$ の光電子ピークは束縛ポテン シャルの内側の転回点, $6.0 \mathrm{eV}$ の光電子ピークは外側の 転回点にそれぞれ対応している。実験では $6 \mathrm{eV}$ 付近の光

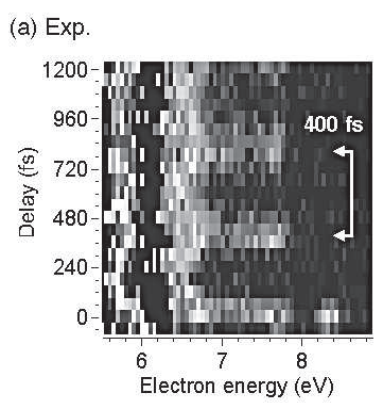

(b) Sim. : $X^{2} \Pi_{1 / 2 g}$

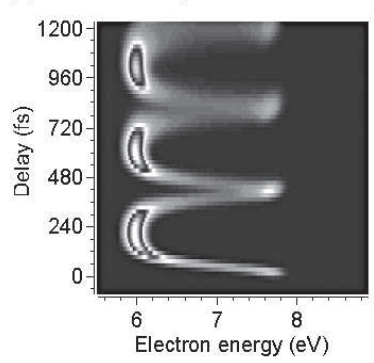

Fig. 6 (a) Photoelectron spectra of vibrational wave packet of $\mathrm{I}_{2}$ in the $\mathrm{B}^{3} \Pi^{+}{ }_{0 u}$ state as a function of time delay between pump $(h v=2.25 \mathrm{eV})$ and probe $(h v=15.5 \mathrm{eV})$ pulses. The dark vertical area at the electron energy of $6.2 \mathrm{eV}$ represents the suppression of the molecular photoelectron signal from $X^{2} \Pi_{3 / 2 g}$ (see Fig. 5 (b)). (b) Simulated photoelectron spectra of $\mathrm{I}_{2}$ in the $\mathrm{B}^{3} \mathrm{\Pi}^{+}{ }_{0 \mathrm{u}}$ state. 
電子ピークは $\mathrm{I}_{2}$ 分子の光電子ピークと重畳しているた め, 信号として観測されていないが, 理論計算は実験結 果をよく再現している. この結果は, 極紫外の単一次数 高調波を光電子計測のプローブ光源として用いること で, $\mathrm{I}_{2}$ 分子の振動波束運動を振動変位のほぼ全域で追跡 できることを示している.

\section{$4.3 \mathrm{~N}_{2}$ 分子のリュードベリ波束ダイナミクス}

極紫外域の超短パルスを用いることで, 高励起状態の 電子波束ダイナミクスを実時間で追跡できる。ここで は, 単一次数高調波パルス $(h v \sim 15.5 \mathrm{eV})$ をポンプ光源 として利用した窒素 $\left(\mathrm{N}_{2}\right)$ 分子のリュードベリ波束ダイ ナミクスの超高速光電子分光計測について述べる.

Fig. 7 (a)に極紫外ポンプおよび近赤外プローブによ る2色 2 光子光電子分光の概略図を示す. 単一次数高調波 パルス $(h v=15.5 \mathrm{eV})$ により $\mathrm{N}_{2}{ }^{+}$イオンの電子基底状態 $\left(\mathrm{X}^{2} \Sigma_{\mathrm{g}}^{+}\right)$および励起状態 $\left(\mathrm{A}^{2} \Pi_{\mathrm{u}}\right)$ に収斂するリュードベリ 状態に波束を生成する。近赤外光 $(h v=1.55 \mathrm{eV})$ 照射に より，この高励起 $\mathrm{N}_{2}$ 分子をイオン化し，リュードベリ 波束の時間発展を実時間追跡する.

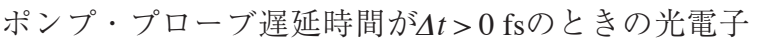
スペクトルには5 本の光電子ピークが観測され, それぞ れのピークエネルギー位置から, これら5本の光電子 ピークは $\mathrm{N}_{2}^{+}$イオン $\mathrm{X}^{2} \Sigma_{\mathrm{g}}^{+}$状態における振動準位 $(\mathrm{v} "=0-4)$ に対応していることが明らかとなった。ポンプ・プロー ブ遅延時間を変えながらこれらの光電子ピーク強度の時 間変化を計測したところ, v" $=0$ の光電子ピークが $0-$ $800 \mathrm{fs}$ の領域において周期287(5) fsの明瞭なビート構造 を示した (Fig.7 (b)).

ポンプ光により励起される主なリュードベリ状態は $\mathrm{N}_{2}{ }^{+}$の $\mathrm{X}^{2} \Sigma_{\mathrm{g}}^{+}$状態に収斂する $9 \mathrm{p} \pi\left(\mathrm{v}_{\mathrm{X}}=0\right)$ および $\mathrm{A}^{2} \Pi_{\mathrm{u}}$ 状態に 収斂する $3 \mathrm{~d} \delta\left(\mathrm{v}_{\mathrm{A}}=1\right)$ に帰属される ${ }^{16)}$ 。この状態間のエネ ルギー差 (約 $100 \mathrm{~cm}^{-1}$ ) から見積もった振動周期は約 $300 \mathrm{fs} て ゙ あ り ，$ 実験結果とよく一致する。このことは，

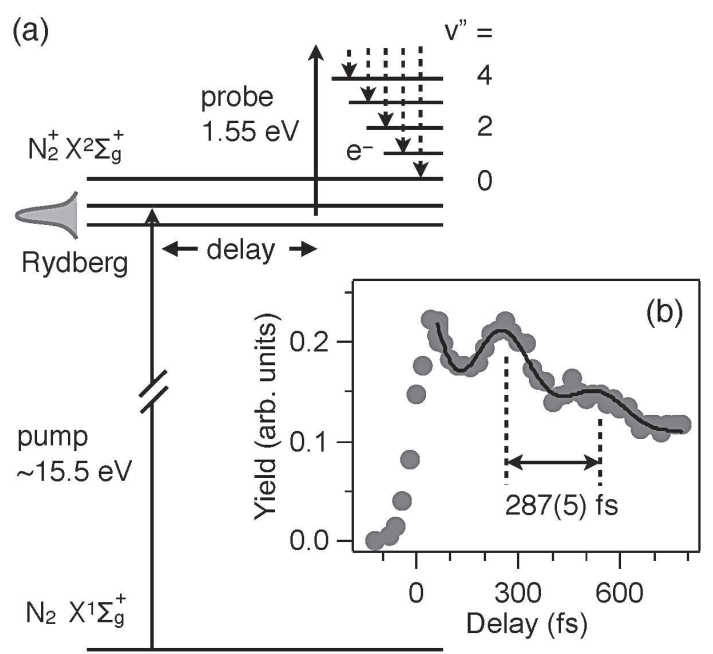

Fig. 7 (a) Schematics of EUV-pump $(h v \sim 15.5 \mathrm{eV})$ and NIR-probe $(h v=1.55 \mathrm{eV})$ photoelectron spectroscopy of $\mathrm{N}_{2}$ molecules. (b) Temporal behavior of integrated intensity of photoelectron peak assigned to $\mathrm{v}^{\prime}=0$ in the $\mathrm{X}^{2} \Sigma_{\mathrm{g}}^{+}$state of $\mathrm{N}_{2}{ }^{+}$ion.
このビート構造がリュードベリ電子 $(9 \mathrm{p} \pi, 3 \mathrm{~d} \delta)$, イオ ンコア電子 $\left(\mathrm{X}^{2} \Sigma_{\mathrm{g}}^{+}, \mathrm{A}^{2} \Pi_{\mathrm{u}}\right)$, 核振動 $\left(\mathrm{v}_{\mathrm{X}}=0, \mathrm{v}_{\mathrm{A}}=1\right)$ からなる 多自由度の波束ダイナミクスを反映していることを示し ている。

\section{5. おわりに}

本稿では，金属薄膜などの光学素子を用いた極紫外域 の単一次数高調波発生と, これを光電子分光に応用し た，超高速分子過程や高励起リュードベリ電子波束の実 時間計測について紹介した。こうした極紫外域のコヒー レント光源は分子の反応過程, 電子・振動波束運動のみ ならず，円偏光高次高調波によるキラル分子の光電子円 二色性 ${ }^{17)}$ や表面磁性体の磁気円二色性 ${ }^{18)}$ など, 今後さま ざまな分子ダイナミクスの実時間計測への応用が期待さ れる。

\section{謝 辞}

ここで紹介した研究は松田晃孝博士(名古屋大学) お よびF. Légaré博士 (INRS-EMT, Canada) との共同研究によ る成果である。本研究の一部は科学研究費補助金, JST さきがけ，(財)東レ科学振興財団，（財)松尾学術振興財 団および(財)伊藤忠兵衛基金からの支援を受けて行われ た。

\section{参考文献}

1) J. Bokor: Science 246 (1989) 1130

2) C. Bressler and M. Chergui: Chem. Rev. 104 (2004) 1781.

3) L. X. Chen: Ann. Rev. Phys. Chem. 56 (2004) 221.

4) T. Brabec and F. Krausz: Rev. Mod. Phys. 72 (2000) 545.

5) M. Drescher, M. Hentschel, R. Kienberger, M. Uiberacker, V. Yakovlev, A. Scrinzi, T. Westerwalbesloh, U. Kleineberg, U. Heinzmann, and F. Krausz: Nature 419 (2002) 803.

6) F. Calegari, D. Ayuso, A. Trabattoni, L. Belshaw, S. De Camillis, S. Anumula, F. Frassetto, L. Poletto, A. Palacios, P. Decleva, et al.: Science 346 (2014) 336.

7) E. J. Takahashi, T. Kanai, K. L. Ishikawa, Y. Nabekawa, and K. Midorikawa: Phys. Rev. Lett. 101 (2008) 253901.

8) N. Ishii, K. Kaneshima, K. Kitano, T. Kanai, S. Watanabe, and J. Itatani: Nat. Commun. 5 (2014) 3331.

9) S. Adachi, T. Horio, and T. Suzuki: Opt. Lett. 37 (2012) 2118.

10) M. Fushitani, A. Matsuda, and A. Hishikawa: Opt. Express 19 (2011) 9600

11) H. Igarashi, A. Makida, M. Ito, and T. Sekikawa: Opt. Express 20 (2012) 3725 .

12) L. Nugent-Glandorf, M. Scheer, D. A. Samuels, A. M. Mulhisen, E. R. Grant, X. Yang, V. M. Bierbaum, and S. R. Leone: Phys. Rev. Lett. 87 (2001) 193002.

13) P. Wernet, M. Odelius, K. Godehusen, J. Gaudin, O. Schwarzkopf, and W. Eberhardt: Phys. Rev. Lett. 103 (2009) 013001.

14) M. Fushitani, A. Matsuda, and A. Hishikawa: J. Electron Spectrosc. Relat. Phenom. 184 (2012) 561.

15) P. B. Corkum: Phys. Rev. Lett. 71 (1993) 1994.

16) C. Jungen, K. P. Huber, M. Jungen, and G. Stark: J. Chem. Phys. 118 (2003) 4517.

17) A. Ferré, C. Handschin, M. Dumergue, F. Burgy, A. Comby, D. Descamps, B. Fabre, G. A. Garcia, R. Géneaux, L. Merceron, et al.: Nat. Photon. 9 (2015) 93.

18) D. D. Hickstein, F. J. Dollar, P. Grychtol, J. L. Ellis, R. Knut, C. Hernández-García, D. Zusin, C. Gentry, J. M. Shaw, T. Fan, et al.: Nat. Photon. 9 (2015) 743. 